\title{
"Dhangdhang Bang Bunghalan Tattwa" Text in the Development of Emotional Intelligence in the Global Era
}

\author{
Ni Putu Parmini ${ }^{1 *}$, Mukhamdanah Mukhamdanah², Dewi Khairiah ${ }^{2}$ \\ ${ }^{1}$ IKIP Saraswati Tabanan, Indonesia \\ ${ }^{2}$ Badan Riset dan Inovasi Nasional, Indonesia \\ *Corresponding author. Email: parminiputu2019@gmail.com
}

\begin{abstract}
This study aims to describe the emotional intelligence contained in the Dhangdhang Bang Bunghalan Tattwa Text. The discussion includes the development of people's emotional intelligence in the global era which can be done through the study of the Dhangdhang Bang Bunghalan Tattwa Text. The theories used in this study were the narrative discourse, semiotic and reception. The study uses Hermeneutic approach. The results show that the Dhangdhang Bang Bunghalan Tattwa Text contains an appeal for the development of emotional intelligence. Emotional intelligence can be developed through giving examples, appeals for togetherness behavior, polite language and habituation in problem solving. Through the implementation of the teachings contained in the text, it can direct Hindus in particular to always be wise, patient, and ethical in their behavior in the global era. This can be done through Pandita (high priest) who transfers the teachings contained in the Dhangdhang Bang Bunghalan Tattwa Text.
\end{abstract}

Keywords: Tattwa Text, Emotional Intelligence, Global Era.

\section{INTRODUCTION}

Fitriana and Suharno state that the success of one's life is not only determined by reason but also by emotional intelligence [1]. Emotional intelligence can be fostered and developed through group guidance service. Ardiana states that behavior in health service based on emotional intelligence support the achievement of quality service [2]. In addition, Purnama also states that a person's level of emotional intelligence is also influenced by education [3]. One type of education that is believed to increase intelligence is moral education. Tattwa Dhangdhang Bang Bunghalan Text contains moral education that must be carried out by Pandita (high priest). Furthermore, the implementation of moral education is transferred by Pandita to the community, because of his duty as a community protector. Boediono states that classical ballet education affects emotional intelligence, because it demands emotional control from dancers [4]. Music feeling stated by Priyanti and Setyowati can be used as a medium for optimizing emotional intelligence for early childhood [5]. Saputra states that emotional intelligence can be improved through studying Balinese gamelan [6].

Along with the development of science and technology which is increasingly global, the need for the development of emotional intelligence, especially in children, is very urgent. The urgency will become clear after monitoring the function of emotional intelligence itself. Emotions are adaptive. Riots occur as a result of uncontrolled emotions. The pressures in social interactions can lead to disasters such as depression, anxiety and personality disorders. Similar disorders have been found in some cases to be overcome by drinking alcohol or drugs.

Emotional intelligence in this paper is presented from the author's understanding of the Tattwa Dhangdhang Bang Bunghalan Text, to help shape the intelligence of society, especially in children. In social life, children are often found to be irritable and angry, even to the point of suicide. It can be 
controlled by giving advice, examples, evidence to stabilize his emotions. The emergence of fear, jealousy, slander, envy and the like are actually people who do not understand the teachings of religion or the teachings of the truth. Divorce and the treatment of ignorant terrorists are also the result of a lack of education or understanding of character education and lack of emotional intelligence.

According to Shapiro, emotion is not merely a genetic factor but a chemical reaction, which is present in special biochemical compounds produced by the brain and results in the body reactions [7]. Emotional intelligence can also be developed through the help of understanding developmental psychology, neural anatomy. A simple idea that can be used to control the emotions of children who tend to fight and make fun of their friends is implementing the teachings in the Dhangdhang Bang Tattwa Text. The text contains the teachings of Yoga, the Godhead, Karma Phala, and Tat Twam Asi (Spiritual teachings).

The spiritual teachings contained in the text if they are truly understood will be able to be developed in the establishment of emotions and character of students. In addition, it can be collaborated with games, stories, using tips related to sociolinguistic theory and other methods that are relevant to the situation.

The Tattwa Dhangdhang Bang Bunghalan Text is stored in the Documentation and Cultural Center (Pusat Dokumentasi dan Budaya) of the Bali Province. The text contains the nature of life and religious human life that should be implemented by Hindus through Pandita. The text contains the teachings of Kapanditan. A Pandita in the text is stated to be in charge of providing protection to the people. A Pandita is a role model for people, especially in the implementation of Hindu teachings. In the Kapanditan teachings, a Pandita is advised to purify oneself, a Pandita always respects the teacher, is able to provide enlightenment to the people, is emotionally, spiritually, socially and intellectually intelligent. Especially emotional intelligence is a reflection of a Pandita. A Pandita is always wise to serve the people.

The study of Tattwa Dhangdhang Bang Bunghalan text used several theories, including the following: (1) Narrative Discourse by Genette (1983) [8]. Discourse as an area of language, as a particular way of speaking, writing and thinking. Discourse is closely related to emotional, socio-cultural and communication; (2) Semiotic Theory by Ratna (2009) was used in interpreting signs in the text associated with denotation [9]. The signs in the Dhangdhang Bang Bunghalan Tattwa text are interpreted and then adjusted according to the context in the meaning process. (3) Reception Theory by Iser (1987) in which the reader can creatively give meaning to the text or discourse [10].

Related to the emotional intelligence of a Pandita and the existence of emotional phenomena in social interaction, the author examines the Dhangdhang Bang Bunghalan Tattwa text in the development of emotional intelligence. On the other hand, in accordance with the government's appeal, the preservation of the nation's cultural heritage is very important in the era of globalization. The problem of this research is "How does the Dhangdhang Bang Bunghalan Tattwa text develop emotional intelligence in the global era?" aiming to describe the emotional intelligence contained in the mentioned text.

\section{METHODS}

The data were collected from the Tattwa Dhangdhang Bang Bunghalan text stored in the Documentation and Cultural Center of the Bali Province. The text is written in Kawi language. The text was then translated by Ida Pandhita Empu Jaya Wijaya [11]. The researcher acquired the data in the form of paragraph. To analyze the data, the method/approach used was Ricoeur's Hermeneutic approach in Muliadi (2020) [12]. By adhering to the nature of the text, it is autonomous and the reader can interpret it himself.

\section{THE DEVELOPMENT OF EMOTIONAL INTELLIGENCE IN THE TATTWA DHANGDHANG BANG BUNGHALAN TEXT}

In the Tattwa Dhangdhang Bang Bunghalan text, it is implied that a Pandita who must achieve true knowledge, is free from emotions such as wanting to be in power, wants to appear the most intelligent, free from envy. The appeal for the development of emotional intelligence contained in the text is as follows.

\subsection{Controlling Emotions by Setting an Example}

Emotional control in the teachings of Hinduism is an attempt by the people to control Sad Ripu (the six enemies that exist in human). The six enemies are able to control themselves such as not being irritable, 
not being drunk, not being jealous, not lying, not being arrogant and not being slanderous [13]. The appeal to control emotions by setting an example is reflected in the Dhangdhang Bang Bunghalan Tattwa text as follows:

"Ia Awighnamastu. Hana sira wuwusan dang walaka reuni jnana, Sang Matapa ring rajya, Sang Mahyun tumingalakna prayojananing suka wahya, Sang Kumingkin wahya ring jati nirmala nunya tunggeng, kinama Sang Apatra Dhangdhang Bang Bunghalan, Sang Aparah tan len, hana ta anak nira jalu-jalu, Sang Makasih-kasih macan angudang, anom listuhayu, sira ta maka ngaran Sang Saptati, Sirata umandhem anembah ri Sang Adya Bapa, tumawaknaken saprayo jananing Sang Wiku. Yatika tinak wanaken Sang Saptati ri Sang Yayah, Sang Aparah tan len. Uduh tangan - tangan panembah ipun Saptati, ri Ibu Tala Pakanira pwangkulun, atadhaga wuwunan ipun Saptati, ahyun warahen ri kalinganing eyopadena."

The translation of the text is:

"He (Sang Saptati) came to face while worshiping his father who he respected (then) asked all the meanings of science including the name of each science. And the most important thing is the life purpose of a Wiku. That is what Sang Saptati asked his father named Tan Len, "O my father, accept the worship of Sang Saptati servant to the dust of the soles of your feet, tread on my crown. I want to be taught about religious teachings, moral teachings, self-control or emotions, especially all the beliefs of a Wiku so that I become confident, consistent and able to make decisions without hesitation." This was the statement of Sang Saptati, as he drew near to worship at his father's feet."

The quote above is a teaching to not be lazy, diligent, patience to study about religion, courtesy, respect for elders, not in a hurry to decide something but always consider wisely before making decision so there will be no hesitation.

In the global era, there are many cases where children disobey and even berate their parents. This is not in line with the teachings of emotional control in the Dhangdhang Bang Bunghalan Tattwa text. The text implies the development of emotional intelligence that no matter how irritated the child to parents, the child must remain respectful and polite and serve parents steadfastly and sincerely. The next text states:

"Tan ikang siddhi panegerannya Sang Tuhu Wiku. Kasakti, nga. Tan ikang kasaktian panegerannya Sang Tuhu Wiku. Manawijana, nga.
Tan ikang kaprajnanan panegeranina Sang Tuhu Wiku Ngaranya."

It is translated as:

"Not because of his supernatural powers he can be called a True Wiku. Not because his intelligence characterizes a person called a True Wiku. Not because of his naivety as a hallmark of a True Wiku but how he can be wise."

The quote states that a person is said to be a true Pandita not because of his supernatural powers, intelligence, innocence, courage, but is a person's ability to manage emotions. Controlled emotions will keep a Pandita away from the attitude of wanting to stand out/show off, but the tendency to do good and create a peaceful atmosphere, and always do, say and think good.

Another part of the text is talking about speech control especially when worshipping to God:

"Lihah pwa kita yan pinaka papa Sang Manon, ikang tutur hidhep, aywa, tutur tinuturaken, aywa ta hidhep hingidhep aken, ndah kapanggih kamoksan."

Translation:

"As you understand, that Sang Manon looks poor, suffering, that is consciousness (normal). Words that have been revealed should not be mentioned. If you cannot control the feeling of eternal freedom, it will go further and further."

The text says that a Pandita must be able to control emotions, think, say and do good. Likewise, it can be taught and exemplified to the people. The attitude of giving examples in the text is also related to the attitude of giving examples in the use of language as a reflection of one's attitude. Chaer and Agustina gave an example that to use Indonesian language correctly, one should show positive attitude towards the language. So, there will be a kind of motivation for Indonesian natives to use the language and prevent them from being low in self-esteem to communicate using the language in the global era [14].

\subsection{The Development of Mutual Behavior}

The Dhangdhang Bang Bunghalan Tattwa text implies a message about togetherness, that the teaching of the kapanditan directs the behavior of togetherness in life. Attitude of togetherness increases individual's social status. Thus, it will broaden the horizons of heterogeneous social life, accept each other's differences therefore they can be 
accepted in any environment. This togetherness behavior is shown in the following quote:

"Mregha paksi, mina, taru, lata, gulma sthawara sasihrepa, pepelika, kekelika, tan weruh siranakira pwangkulum."

which is translated as:

"Although in the form of pets such as birds, rooster, creeping animals and other types of animals, they still have togetherness as living beings."

The attitude of togetherness is also reflected in the following quote:

"Sumahur Sang Aparah Tan Len, Alan anakku Sang Saptati, alupa kami tuturen kami dentanaku, karuhun prayojana, ri patakwanta, mekanekan Sang Hyang Dharma ri kami. Pisaningun prayojananing aji saji mwang ring eyopadewa, tlas karuhun sakweh sadhya pakua Sang Wiku. Pahenak denta rumengo sabdhamami, Sang Saptati. Dwitiye pakuaye Bhikuu, buddhayenair aurayam, buddhaye bahu bhawasam kriye bhede prakirttitah. Kalinganya, Sang Saptati, rwa paksa Wiku, ngan. Lwirnya: kabuddhayan lawan kanisrayan Ikang kabuddhayan paksa, yati."

The translation is

"The one named Tan Len replied, "Alan my son Sang Saptati, I almost forgot to explain (about) my father. Regarding your question, asking about the teachings of Religion including the purpose of all knowledge and about upadesa, the important thing is the nature that is the basis and goal of a Pandita's belief. Sang Saptati listen to my words, which means that there are two types of beliefs of the Pandita, namely Kabudhayan and Kanisraya. Rules belonging to kabuddhayan, culture, cause confusion for the eyes because of their many forms and changes. All kinds of things are traversed together.

The quote above implies that in order to learn all knowledge, one should be willing to listen to the advice of teachers and of those who know better. The importance of togetherness in studying is so that it does not cause confusion. This is in line with what was stated in Geguritan Sidha Yoga Krama that helping each other and togetherness can improve emotional quality [15]. Yasa adds that togetherness, especially in education circles, can be done by implementing the values of local wisdom [16]. The development of emotional and intellectual intelligence, joint problem-solving efforts have a positive impact on improving the quality of personality.

\subsection{The Development of Polite Language Skills}

Polite language can be expressed through specific behaviors, such as greetings to friends, greetings to adults, gratitude to someone who helps. It is said in clear and polite views and words that show sincerity and respect and gratitude [7]

The call for polite language is implied in the following quote:

"Wruh pwa kita yang pinaka papa Sang Manon, ikang tutur hidhep, away tutur tinuturaken, away ta hidhep hingidhepaken, ndah kapanggih tang kamoksan, apan kabukti ikang halahayu, paran kabhukti, paran pamukti, apan hana tutur hidhepira Sang Manon, apan huwus tuninggalaken drebyanira, sira ta haneng anta hrdehaya ngaranya, patengah tengahing halahayu, sira ta maka haran Si Anu, yata Anoman ngaranya, Mapa dening padka Si Anu apan manuduh, apa dening tuminghala Si Anu, apan tuminghal, wruh pwa kita Sang Saptati, away ta mangucap angajaraken, hana inajaraken ta, hana inajaraken ta, hana pinaka papanta, norana inajaraken, nora pinaka papanta. Kalinganyanakku, Sang Saptati, Wruh pwa yatna heneng."

The translation is:

"O my son Sang Saptati, understand carefully, be calm and be silent about his behavior. There is no point in discussing or talking about Him. Better work well and be successful. Get your work done, don't be rude. Speak politely and politely. Be patient, don't talk nonsense. So, it's over and Dad, the time has come to finish your lesson with Sang Saptati. This is what Kanirasrayan termed, liberation. The teacher has finished his task of teaching you a lesson. You have also graduated from the status of being a student. Ananda's desired destination has been found."

The quote above implies that polite, respectful and obedient language to teachers greatly supports the success of achieving goals in studying. Mastery of knowledge is also determined by emotional intelligence such as, in the use of language that reflects patience, politeness, wisdom and respect, especially to teachers. Related to the use of polite language in the text as a cultural heritage, Indonesian language serves as a medium for accommodating national culture. Sasangka states that various languages can be used both in formal and informal settings, as long as they can be understood and do not deviate from the rules of using Indonesian language [17]. The appeal for politeness in language in the 
Dhangdhang Bang Bunghalan Tattwa text is in line with character education proposed by Chanifah that the use of polite language is one of the reflections of one's character [18]. Wibowo has explored the use of integrated language with character education [19]. Through the use of language, the habituation of politeness and politeness can be instilled.

\subsection{Habit Development in Problem Solving}

Habits in problem solving can be achieved if a Pandita has realized and has insight about the natural things of God's creation. This is illustrated in the following quote:

"Sang Apatra Dhangdhang Bang Bunghalan. Hai Sang Saptati, Nihan upamanya, kadyangganing wilalang Sang Manon, tumraping pager tan mihu watu, hiwa mangkana ta Sang Manon, tumraping pati tan milu pati, tumraping hurip tan milu hurip, apa hetu nira yan mangkana. Yan tahankwa lingangtanaku, apan sira maka huriping hurip, Ya ta sokaton sakarengo denta, marupa warna, sahana sahan nika, humoring taya, humoring sunya, melah mambekan masabdha Yatika kahananira Sang Manon maweh hurip pinaka huripnya. Hai Sang Saptati, wruh kanika kalinganing Tan Len sumahur Sang Saptati, ringnira, Wihikan Mangku."

It is translated as:

"Dhangdhang Bang Bunghalan replied. O Sang Saptati, this is the parable of Sang Manon like a dragonfly, perched on a fence, not being there. Perched on the ground does not become soil. Perched on a rock does not become a stone. So is Sang Manon. Staying in the wind doesn't become the wind. Staying on sound doesn't become sound. What He wills so happens. We can try. His human problems also animate. He was the living source of everything Ananda saw and heard. Everything that is tangible, colored, that merges with silence, that moves, that speaks, that thinks, all of that was created by Sang Manon. It was Sang Manon who was pleased to bestow life as his soul. Hi Sang Saptati know that as Tan Len said, Sang Saptati now understands it."

The quote explains that everything that exists and happens in the world is because of God/Deity. In discussing problems, one should ask for His blessing, therefore the issues discussed can be discussed wisely and successfully, without tension. Regarding problem solving, Fajar states that problem, critical thinking, anxiety, concern for the environment as his creations can be discussed, solved together wisely and can be expressed in the form of literary works [20]. This method is an alternative solution to the problem.

\section{THE DEVELOPMENT OF EMOTIONAL INTELLIGENCE IN THE GLOBAL ERA}

In the global era, it is found in society that the divorce rate is increasing, the negative influence of the screen is pervasive, children's respect for teachers and parents is waning and other cases have an impact on the decline in emotional and social skills. This fact must be accepted, but must also be balanced with efforts to overcome it by increasing emotional intelligence.

The Dhangdhang Bang Bunghalan Tattwa text contains wise attitudes that must be carried out by a Pandita. Then, the Pandita transfers the lessons to the people. Pandita teaches by giving an example or advice to the people. Pandita functions as a role model for Hindus and provides enlightenment to Hindus. The teachings of the Kapanditan, which are contained in the Dhangdhang Bang Bunghalan Tattwa text, can be used as a source in the implementation of the teachings of Hinduism. The content of teachings that direct people to act, say and think well, patiently and wisely makes the Dhangdhang Bang Bunghalan Tattwa text effectively utilized in the development of emotional intelligence in the global era.

This study is merely discussing the emotional aspect within the Dhangdhang Bang Bunghalan Tattwa text. Therefore, the researcher limits this current study to describe from that aspect only.

\section{CONCLUSION AND SUGGESTIONS}

The Dhangdhang Bang Bunghalan Tattwa text contains education that leads to emotional intelligence. The text contains the teachings of the Kapanditan. Pandita serves as a role model for Hindus, so the teachings and advices containing the value of emotional intelligence will be followed by the people. The emotional intelligence that can be formed through the teachings contained in the Dhangdhang Bang Bunghalan Tattwa text are: 1) emotional control by setting an example. The teachings of the Kapanditan are used as examples that lead a person to be patient and always think, say and do good; 2) the development of togetherness behavior. The attitude of helping, having sense of belonging to one another and feeling each other is an attitude that is highly expected; 3 ) the development of polite language skills. The call for polite language skills in the text is contained in Sang Mamon's conversation with Sang Saptati in polite language. In addition, it is also directed to use polite language as a 
reflection of respect for teachers and others; and 4) the development in problem solving. In forming this attitude, people are directed to believe that everything that exists is God's creation and is insightful, be wise towards His creation, care for the environment and others. In problem solving, people should not have high tension, but wisely pay attention and considers comprehensively everything related to the problem. In facing the challenges of globalization, emotional intelligence is important to improve. The attitude of emotional control, wisdom, patience, courtesy and togetherness will be able to create a comfortable and peaceful life atmosphere.

Based on the conclusions, the author suggests that the Dhangdhang Bang Bunghalan Tattwa text should be taught or learned since it contains values that are beneficial for life. In addition, the text needs to be preserved and explored as the nation's cultural heritage, so it does not sink due to the swift currents of globalization.

\section{REFERENCES}

[1] S. Fitriana, A. Suharno, Meningkatkan Kecerdasan Emosional melalui Layanan Konseling Kelompok, Majalah Lontar 24(2) (2010) 1-17. DOI: https://doi.org/10.26877/1tr.v24i2\%20Juli.447

[2] A. Ardiana, Hubungan Kecerdasan Emosional Perawat dengan Perilaku Caring Perawat Pelaksana menurut Persepsi Pasien di Ruang Rawat Inap RSU Dr. H. Koesnadi Bondowoso, Master's Thesis of Universitas Indonesia, 2010.

[3] L. Purnama, Tingkat Kecerdasan Emosional Perawat RSAI Hermina. Jatinegara. Master's Thesis of Universitas Indonesia, 2010.

[4] A. N. Boediono, Perbedaan Kecerdasan Emosional antara Individu yang Mengikuti Pendidikan Balet Klasik dengan Individu yang tidak Mengikuti Pendidikan Balet Klasik, Universitas Indonesia, 2004.

[5] I. Priyanti, N. Setyowati, Optimalisasi Kecerdasan Emosi melalui Musik Feeling Band pada Anak Usia Dini, Jurnal Care 3(1) (2015) 20-33.

[6] G. A. Saputra, 2003. Gambaran Kecerdasan Emosional (Emotional Intelligence) Remaja yang Memilih Mempelajari Gamelan Bali, Universitas Indonesia, 2003.
[7] L. E. Shapiro, Mengajarkan Emotional Intelligence pada Anak, translation: A. T. Kantjono, Gramedia, 2001.

[8] G. Genette, Narrative Discourse: An Essay in Method, Blackwell, 1983.

[9] N. K. Ratna, Metodologi Penelitian: Kajian Budaya Ilmu Sosial Humaniora, Pustaka Pelajar, 2009.

[10] W. Iser, The Act of Reading: A Theory of Aesthetic Response the John Hopkins, University Press, 1987.

[11] Pusat Dokumentasi dan Budaya Provinsi Bali, Tattwa Dhangdhang Bang Bunghalan, translation: I. P. E. J. Wijaya, Pusat Dokumentasi dan Budaya Provinsi Bali, no year.

[12] Muliadi, Teori Kajian Hermeneutika Sastra: Karya Kreatif Mengusung Pembelajaran Nilai Multikultural Solidaritas dalam Teori Sastra Terbaru, Grafika Indah, 2020.

[13] I. B. R. Putra, Swastikarana, Mabakti, 2013.

[14] A. Chaer, L. Agustina, Sosiolinguistik: Perkenalan Awal, Rineka Cipta, 2010.

[15] I M. Degung, Geguritan Sidha Yoga Krama, Parisada Hindu Darma Upadesa, 2013.

[16] I N. Yasa, Spirit kearifan lokal sebagai katalisator virtue intellectual pendidikan: persepktif epistemology, in: Proceedings of the Seminar Nasional Bahasa Sastra dan Pengajarannya IV, Program Studi Pendidikan Bahasa dan Sastra Indonesia Fakultas Bahasa dan Seni Universitas Pendidikan Ganesha, Singaraja, 2016, pp. 487-496.

[17] S. S. T. W. Sasangka, Gapura Bahasa Indonesia, Erlangga, 2013.

[18] N. Chanifah, Desain pendidikan karakter di perguruan tinggi umum, in: Proceedings of the Seminar Nasional Riset Inovatif III, Undiksha Press, Kuta, 2015, pp. 47-51.

[19] A. Wibowo, Pendidikan Karakter Berbasis Sastra. Internalisasi Nilai-Nilai Karakter melalui Pengajaran Sastra, Pustaka Pelajar, 2013.

[20] Y. Fajar, dkk., Sastra Pariwisata Lokalitas: Antologi Esai Sayembara Kritik Sastra Hiski Bali 2020, Mahima, 2021. 